\title{
G1359A Variant of the Cannabinoid Receptor Gene (rs 1049353) and Obesity-Related Traits and Related Endophenotypes: A Meta-Analysis
}

\author{
Mehdi Sadeghian $^{\mathrm{a}, \mathrm{b}}$ Sepideh Rahmani ${ }^{\mathrm{c}} \quad$ Anahita Mansoori $^{\mathrm{d}}$ \\ a Department of Nutrition, Ahvaz Jundishapur University of Medical Sciences, Ahvaz, Iran; bStudent Research \\ Committee, Ahvaz Jundishapur University of Medical Sciences, Ahvaz, Iran; ' Department of Community Nutrition, \\ M.A. Graduate of Nutrition, School of Nutrition, Isfahan University of Medical Sciences, Isfahan, Iran; ${ }^{\mathrm{d}}$ Nutrition and \\ Metabolic Diseases Research Center, Ahvaz Junishapur University of Medical Sciences, Ahvaz, Iran
}

\section{Keywords}

Cannabinoid receptor gene $\cdot$ Polymorphism · Leptin ·

Body mass index · Dietary intake

\begin{abstract}
Background: This study aimed to investigate the comparison of G1359A variant of cannabinoid receptor gene (rs1049353) with obesity-related traits including body mass index (BMI), fat mass (FM), fat-free mass (FFM), food-related traits, and leptin among healthy and non-healthy adults. Methods: We searched PubMed, Cochrane, Scopus, Web of Science, and EMBASE until December 2016 for observational studies assessing each of the anthropometric measurements, food-related traits, and leptin of $1359 \mathrm{G} / \mathrm{A}$ polymorphism of CNR1 gene. A total of 22 studies were included in the meta-analysis comparing mean and SD differences of the anthropometric measurements, leptin, and dietary intake between GA/AA and GG genotypes. Results: The results showed that subjects with GA/AA genotype had significantly lower BMI (weighted mean difference $=-0.59 \mathrm{~kg} / \mathrm{m}^{2}, p<$ 0.001 ) compared to those with the GG genotype. Dietary intake of fat, carbohydrate, and protein as well as serum levels of leptin was not significantly different between GA/AA and GG genotypes. Conclusion: It was revealed that subjects
\end{abstract}

\section{KARGER}

(c) 2018 S. Karger AG, Basel

E-Mail karger@karger.com

www.karger.com/anm with mutant polymorphism (GA/AA) of CNR1, compared to the wild-type group (GG), had lower BMI (although there was unexplained heterogeneity).

(c) 2018 S. Karger AG, Basel

\section{Introduction}

The endocannabinoid system contributes to energy homeostasis and is involved in controlling appetite and body weight [1]. This system consists of endogenous ligands and 2 G-protein coupled cannabinoid receptors (CNRs): cannabinoid type-1 (CB1) receptor is located mainly in the central nervous system and a variety of peripheral tissues including adipose tissue and CB2 receptor are found in the immune system [2]. A silent intragenic biallelic polymorphism in codon 435 of the cannabinoid receptor 1 (CNR1) gene, substitution of G to A at nucleotide position 1359 (1359 G/A rs1049353), was reported to be associated with several disorders like obesity [3], type 2 diabetes mellitus [4], and metabolic syndrome [5]. It is a common polymorphism among different populations, as the frequency of the rare allele (A) carriers was reported to be $24-32 \%$ in German [6] and $48.1 \%$ in Spanish [7] populations. Earlier studies reported an association of A- 
allele (mutant allele) with better anthropometric measurements [8], metabolic profile [3, 7] and adipokines [9] compared to non-A allele carriers (wild type allele). However, other studies failed to find such associations [10-12]. Mixed results have been recently reported considering the association between dietary intake and different genotypes. While the intake of cholesterol and saturated fat was significantly different between genotypes [13], no significant changes in calorie and macronutrient intakes were detected [10]. Findings from clinical trials showed that hypocaloric diets resulted in different outcomes of body weight and metabolic improvement in the polymorphism groups of 1359 G/A of CNR1 gene [14, 15]. Moreover, different study designs along with different health conditions of participants have failed to provide conclusive evidence. This study is the first meta-analysis investigating the comparison of 1359 G/A polymorphism with obesity-related traits, food-related traits, and serum leptin.

\section{Methods}

Search Strategy

Using suggested meta-analysis guidelines [16], we performed a systematic search of human studies in PubMed, Cochrane, Scopus, Web of Science, and Embase until December 2016. The following search criteria were used: ("G1359” or "1359 G/A" or "rs1049353”) and ("body mass index [BMI]" or "Quetelet index" or "fat mass [FM]" or "leptin"). To identify other relevant articles, we also reviewed reference lists of each study. No restrictions were applied for time and language. The protocol has been registered with PROSPERO (registration number CRD42017054204).

\section{Selection Criteria}

We included studies that reported distinct information according to $1359 \mathrm{G} / \mathrm{A}$ polymorphism genotype in the dominant model (G1359A and A1359A genotypes with rare allele (A) as the mutant-type group, versus G1359G as the wild-type group) for; (1) obesity-related traits including BMI, waist circumference (WC), FM and FFM; (2) food-related traits including intake of energy, carbohydrate, protein, fat, saturated fatty acid (SFA), polyunsaturated fatty acid (PUFA), monounsaturated fatty acid (MUFA), and fiber; (3) serum levels of leptin. The dominant model was used in most of the studies related to this topic, and we did not have data to assess recessive or additive models. For clinical trials and cohort studies, only baseline measurements were extracted. In effect, clinical trials were extracted as 2 separate studies according to the reported baseline data for the intervention and control groups. Since 12 out of 22 studies included in the current meta-analysis have been published by the same investigator, the absence of sample overlap in the 12 papers was verified by the author via email.

\section{Data Extraction}

Two reviewers, independently, extracted the following key data: first authors' last name, publication date, study design, research location, participants' age and gender, sample size, number of cases with different genotypes, subjects' race and health condition, SNP detection method, mean and SD for BMI, FFM, FM, WC, leptin, and dietaryintake of energy, carbohydrate, protein, fat, SFA, PUFA, MUFA, and fiber reported distinctly for mutant and wild-type groups.

\section{Quality Assessment of Studies}

Newcastle-Ottawa scale was employed to score the quality of studies included in this meta-analysis [17]. Each study received a maximum of 9 scores. The rationale behind the scores was based on the selection of study groups (mutant versus wild genotypes), comparability of groups, and the substantiation of exposure.

\section{Statistical Analysis}

The statistical analysis for calculating weighted mean difference (WMD) was performed on the mean difference and SD of the abovementioned parameters in the polymorphism groups. The relationship between variables and genotypes was presented as WMD with 95\% CIs. To pool the effect sizes, the fixed effects model was used. When there was heterogeneity among data, the random effects model was used to ensure the power of the chosen model. To find the source of heterogeneity, subgroup analysis was performed. Cochran's Q test and $I^{2}$ metric were employed to evaluate between-study heterogeneity [18]. Heterogeneity was considered statistically significant if the $p$ value was less than 0.01 or $I^{2}>$ $50 \%$. To add robustness, we conducted sensitivity analysis by omitting individual study from the model and analyze the influence of each study on the pooled effect size. The visual inspection of funnel plot and formal analysis of Egger's and Begg's test were, in turn, used to assess publication bias. Data synthesis was performed by Stata software (version 12.0; StataCorp, College Station, TX, USA). Since we evaluated 13 variables, we applied the Bonferroni correction for multiple testing; therefore, we rejected null hypothesis if the $p$ value was $<0.003$.

\section{Results}

\section{Description of Studies}

We identified 108 references from our initial search. After a 2-step screening by 2 different investigators, 22 articles met the inclusion criteria, including 10 cross-sectional [3, 7-10, 12, 13, 19-21], 4 case-control [4, 5, 22, 23], 1 cohort [24], and 7 clinical trial [14, 15, 25-29] studies (Fig. 1). Two studies were excluded as they did not illustrate the information for different genotypes [11, 30], while another study was eliminated, as it was reportedly based on the recessive model [31]. The total number of participants with GG and GA/AA genotypes was 5,133 (62.93) and 3,024 (37.07\%), respectively, with the age range of 29-69. Except 2 studies that were carried out on the Asian population $[5,23]$, other studies were carried out on Caucasians. While most of the studies were conducted in Spain, some were conducted in Germany, Italy, China, Denmark, and Poland. The quality score of the studies ranged from 3 to 10 , with a median of 7 . We con- 
Fig. 1. The flow diagram of the study selection process.

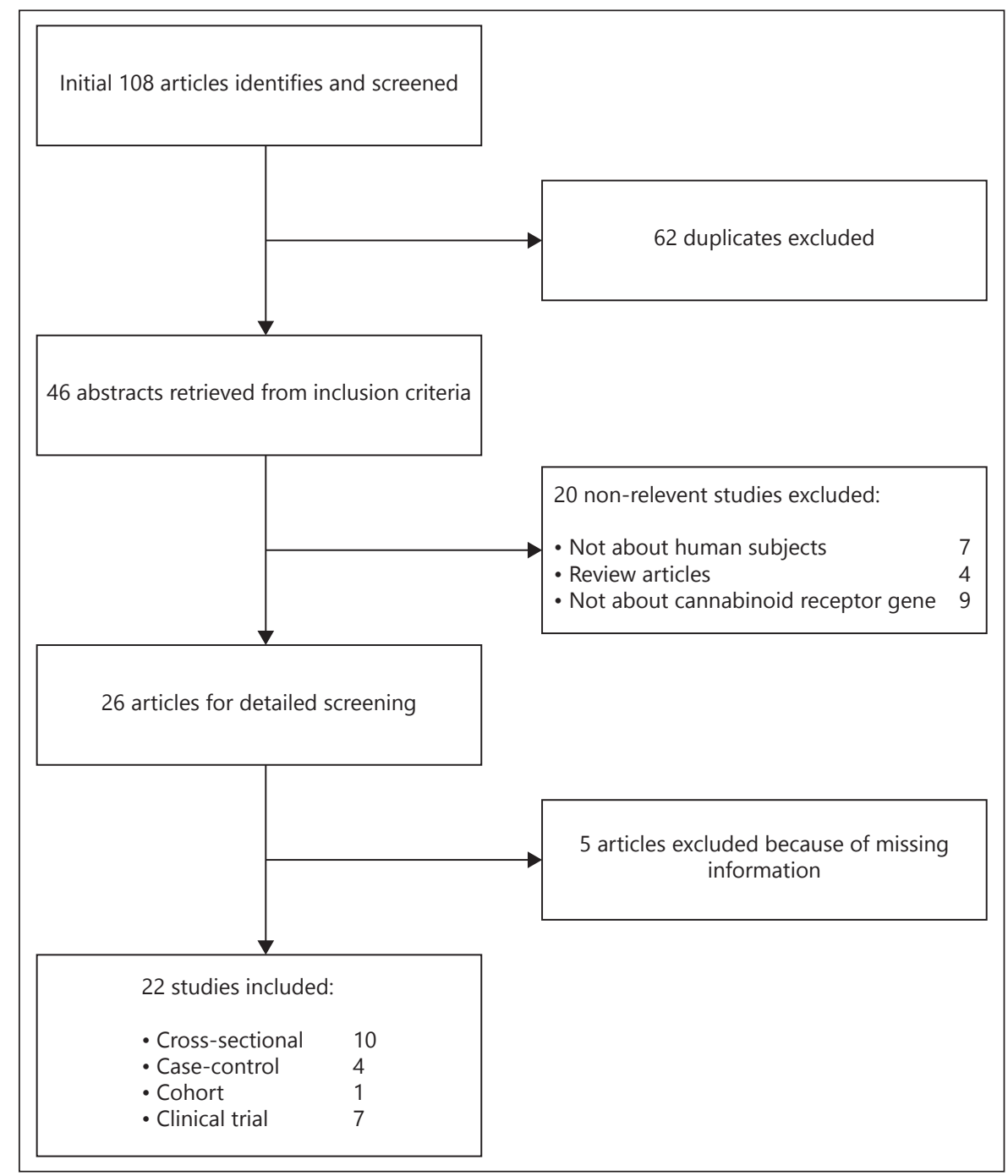

sidered studies with the score of 7 or greater as high-quality studies and those with the score of lower than 7 as lowquality studies (Table 1).

\section{Pooled Analyses}

Obesity-Related Traits

The meta-analysis of 27 point estimates from 22 studies was conducted on mean BMI among subjects with wild and mutant genotypes. Subjects with AA/AG genotype (mutant-type) had significantly lower BMI compared to those with GG genotype (wild-type; WMD $=-0.59 ; 95 \% \mathrm{CI}-1.1$ to $-0.075 ; p<0.001$; Table 2 ), with a significant heterogeneity $\left(I^{2}=73.7 \%, p<0.001\right.$; Fig. 2$)$. No single study altered the overall findings as determined by sensitivity analysis (Fig. 3).

Data combination of 16 estimates from 12 studies did not show a significant difference for FM between subjects with wild genotype compared to those with mutant genotype (WMD $=-0.23 ; 95 \% \mathrm{CI}-0.87$ to $0.41 ; p=0.48$ ). There was also no significant difference for fat-free mass (FFM; $\mathrm{WMD}=-0.62 ; 95 \% \mathrm{CI}-1.76$ to $0.53 ; p=0.29)$. No significant heterogeneity was observed for FM or FFM either.

There were 18 effect sizes from 14 studies for mean differences included in the meta-analysis of waist circumference. No significant difference was found in mutant-type subjects compared to the wild type group (WMD $=-0.55$; $95 \%$ CI -1.54 to $0.45 ; p=0.28$ ), with no significant heterogeneity.

\section{Food-Related Traits}

The overall estimate of 6 publications reporting energy intake showed that there was no significant 


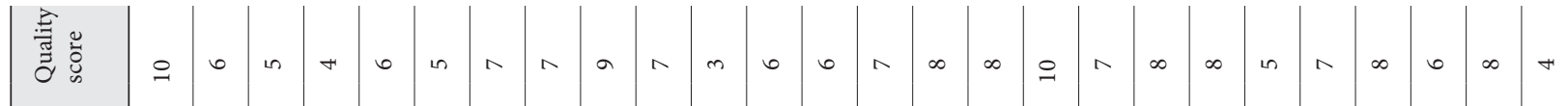

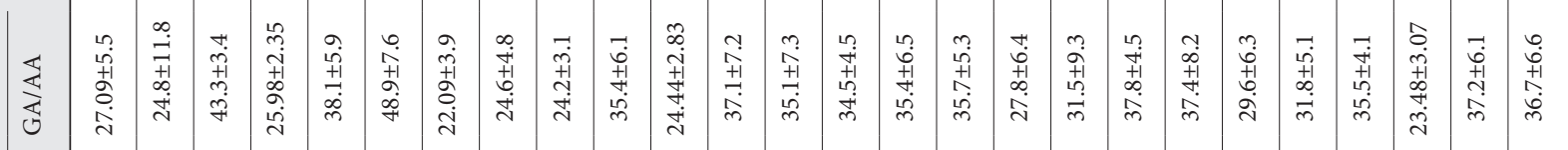

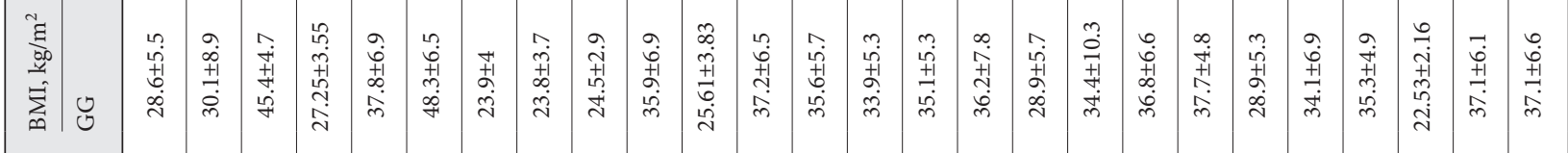

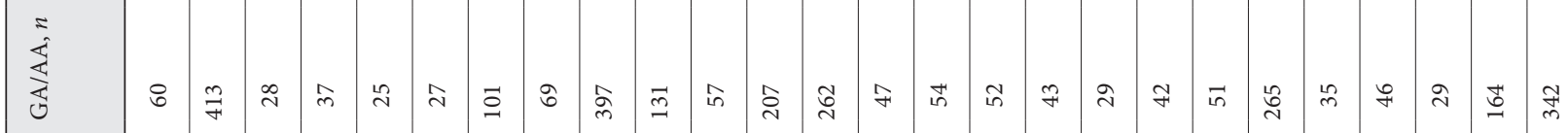

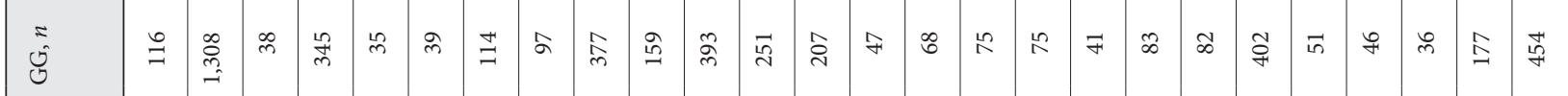

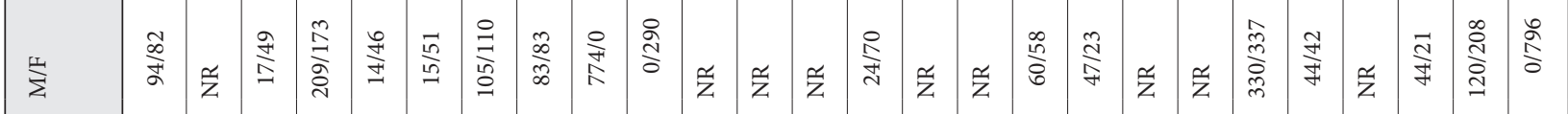

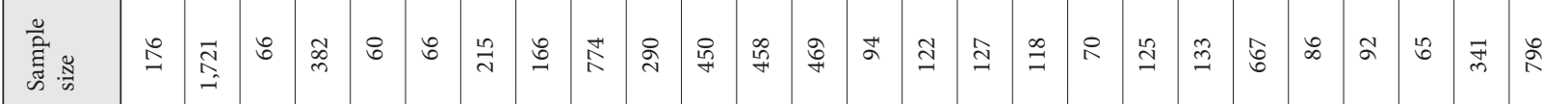

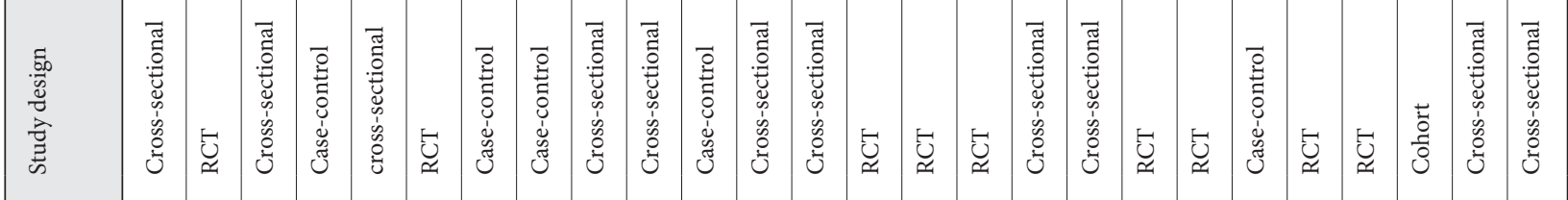

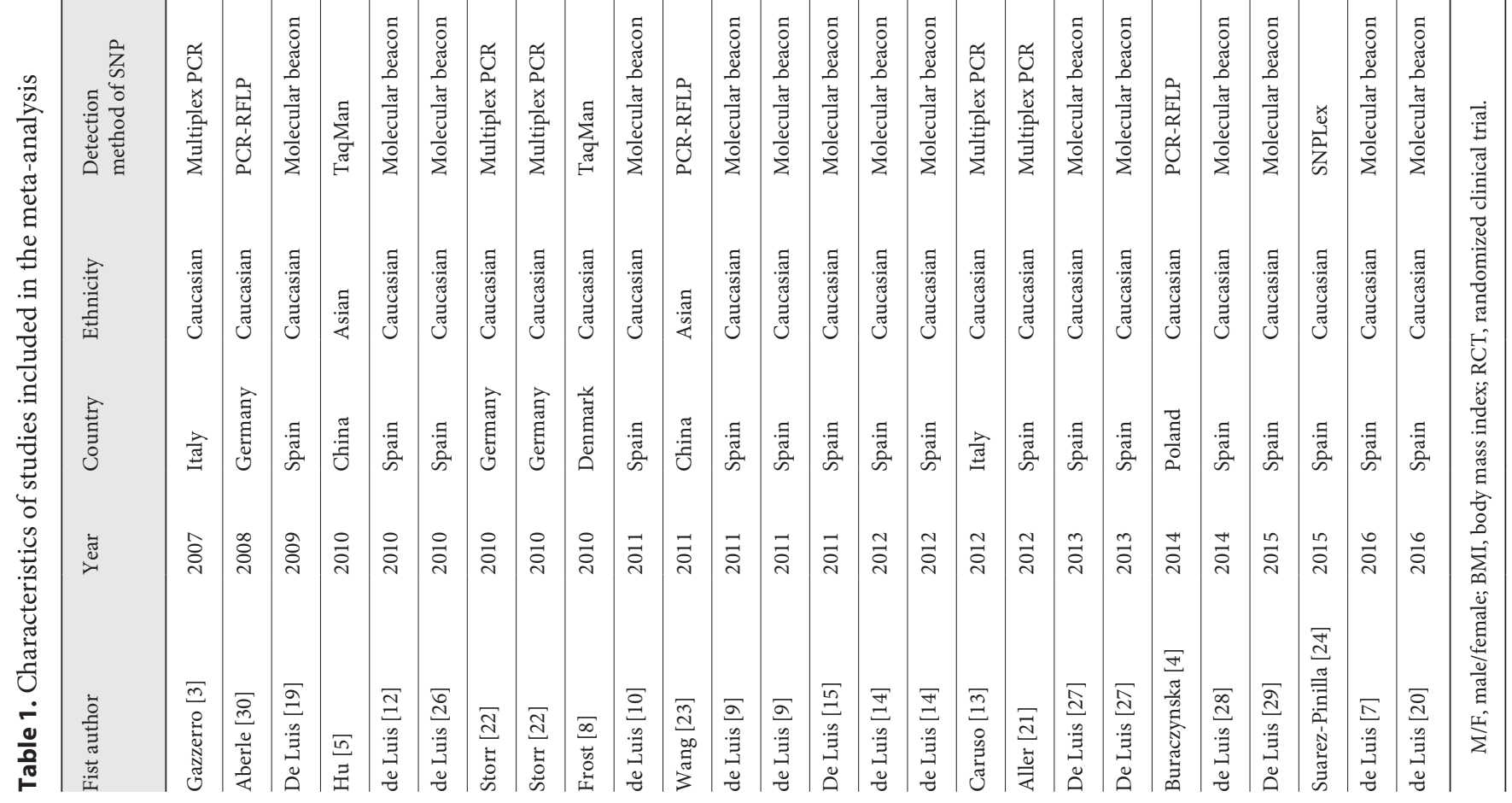


Table 2. Results of meta-analyses

\begin{tabular}{|c|c|c|c|c|c|c|c|}
\hline $\begin{array}{l}\text { Outcome or } \\
\text { subgroup title }\end{array}$ & $\begin{array}{l}\text { No. of } \\
\text { effect sizes }\end{array}$ & $\begin{array}{l}\text { Sample } \\
\text { size }\end{array}$ & References & WMD $(95 \%$ CI $)$ & $p$ value & $I^{2}, \%$ & $\begin{array}{l}p \\
\text { heterogeneity }\end{array}$ \\
\hline BMI, $\mathrm{kg} / \mathrm{m}^{2}$ & 27 & 8,227 & {$[3-5,7-10,12-15,19-29]$} & $-0.59(-0.1 .1$ to -0.075$)$ & $<0.001$ & 73.7 & $<0.001$ \\
\hline FFM, kg & 7 & 1,120 & {$[7,10,12,14,15,28]$} & $-0.62(-1.76$ to 0.53$)$ & 0.29 & 0 & 0.93 \\
\hline $\mathrm{WC}, \mathrm{cm}$ & 18 & 3,875 & {$[5,7,9,10,12,14,15,19-21,26-29]$} & $-0.55(-1.54$ to 0.45$)$ & 0.28 & 12.2 & 0.31 \\
\hline Energy, kcal/day & 6 & 1,424 & {$[10,12,13,15,19,20]$} & $-33.02(-132.45$ to 66.41$)$ & 0.52 & 52.9 & 0.06 \\
\hline PUFA, g/day & 5 & 1,330 & {$[10,12,13,19,20]$} & $-0.44(-0.87$ to -0.001$)$ & 0.05 & 0 & 0.68 \\
\hline MUFA, g/day & 5 & 1,330 & {$[10,12,13,19,20]$} & $-0.96(-2.38$ to 0.47$)$ & 0.19 & 0 & 0.80 \\
\hline Carbohydrate, g/day & 6 & 1,424 & {$[10,12,13,15,19,20]$} & $-2.45(-9.31$ to 4.41$)$ & 0.49 & 0 & 0.87 \\
\hline Protein, g/day & 6 & 1,424 & {$[10,12,13,15,19,20]$} & $-0.60(-2.94$ to 1.75$)$ & 0.62 & 0 & 0.74 \\
\hline Fiber, g/day & 5 & 1,330 & {$[10,12,13,19,20]$} & $-0.26(-0.81$ to 0.30$)$ & 0.37 & 0 & 0.82 \\
\hline
\end{tabular}

Fig. 2. Mean difference of BMI among patients with GA/AA compared with those with GG genotype.

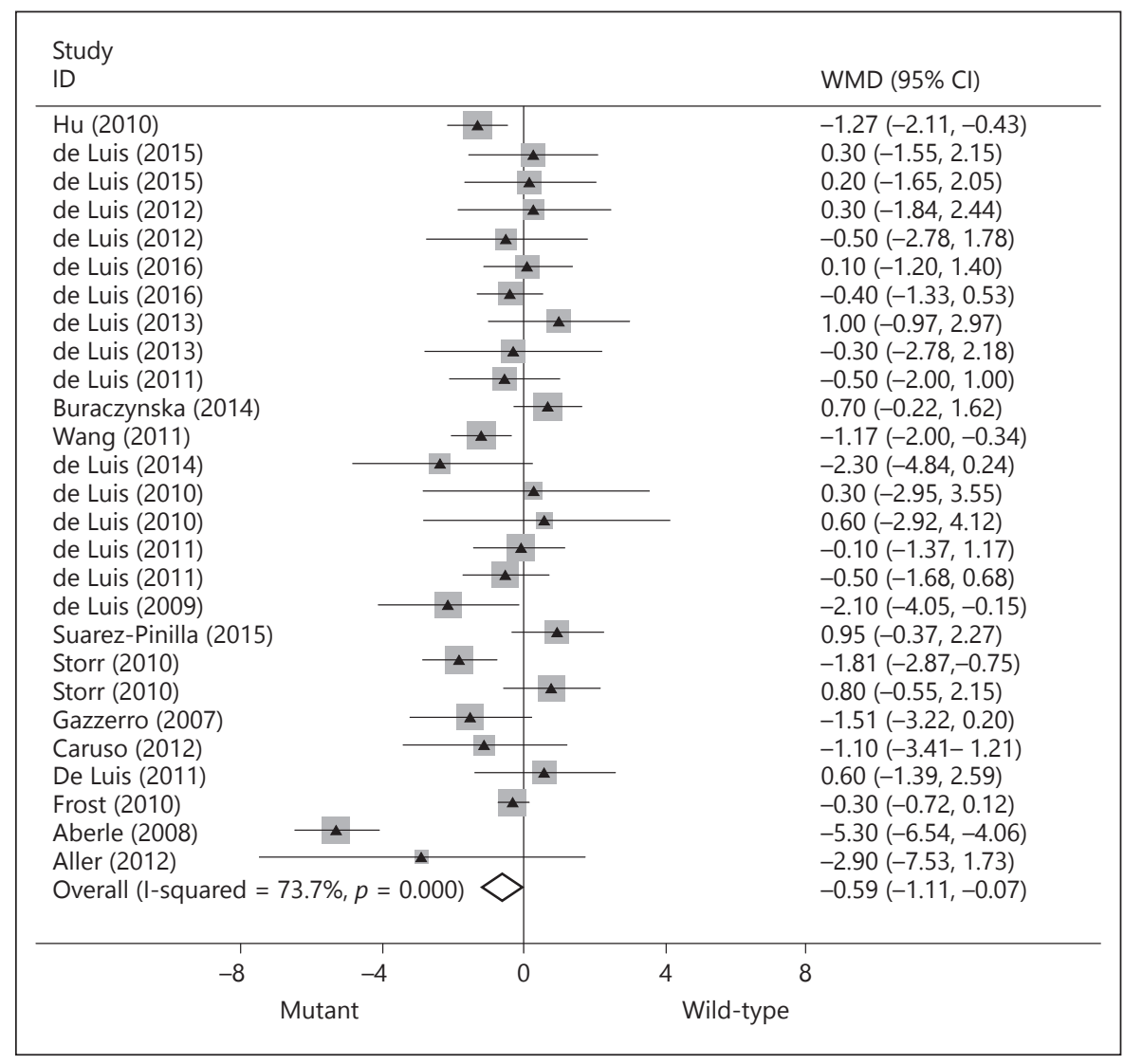

difference between energy intake of subjects with GA/ AA genotype compared to those with GG genotype (WMD $=-33.02 ; 95 \%$ CI -132.45 to $-66.41 ; p=0.52$ ). No evidence of heterogeneity was found. Also, sensitivity analysis did not lead to a significant alteration in the corresponding pooled WMD or did it provide additional information.

The combined estimate of the total fat intake from 6 studies was $-4.60 \mathrm{~g} /$ day $(95 \% \mathrm{CI}-7.91$ to $-1.29 ; p=$ 0.006), with no significant heterogeneity (Fig. 4). Com- 


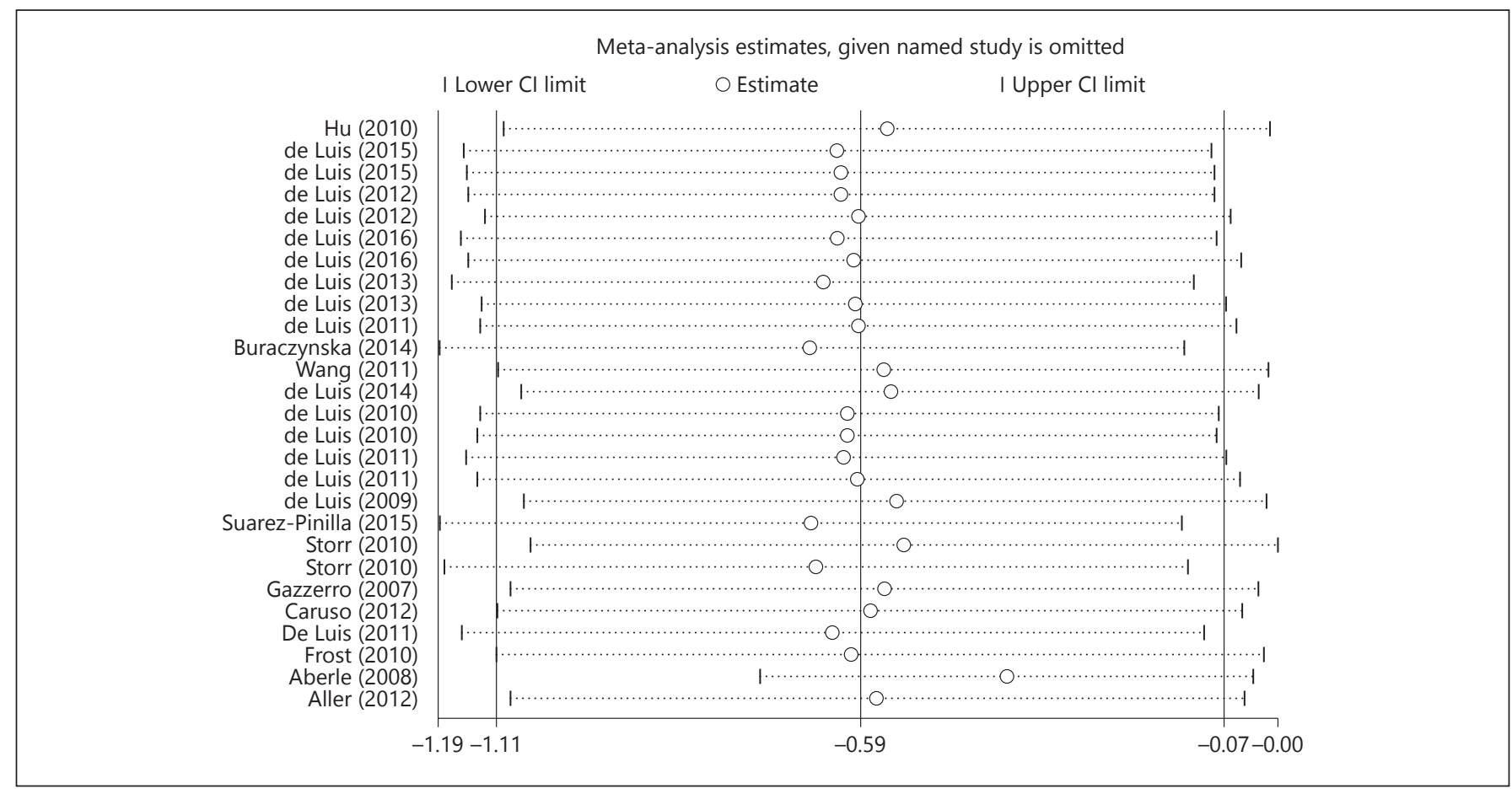

Fig. 3. Sensitivity analysis for the mean difference of BMI among patients with GA/AA compared with those with GG genotype. BMI, body mass index.

Fig. 4. Mean difference of total dietary fat intake among patients with GA/AA compared with those with GG genotype.

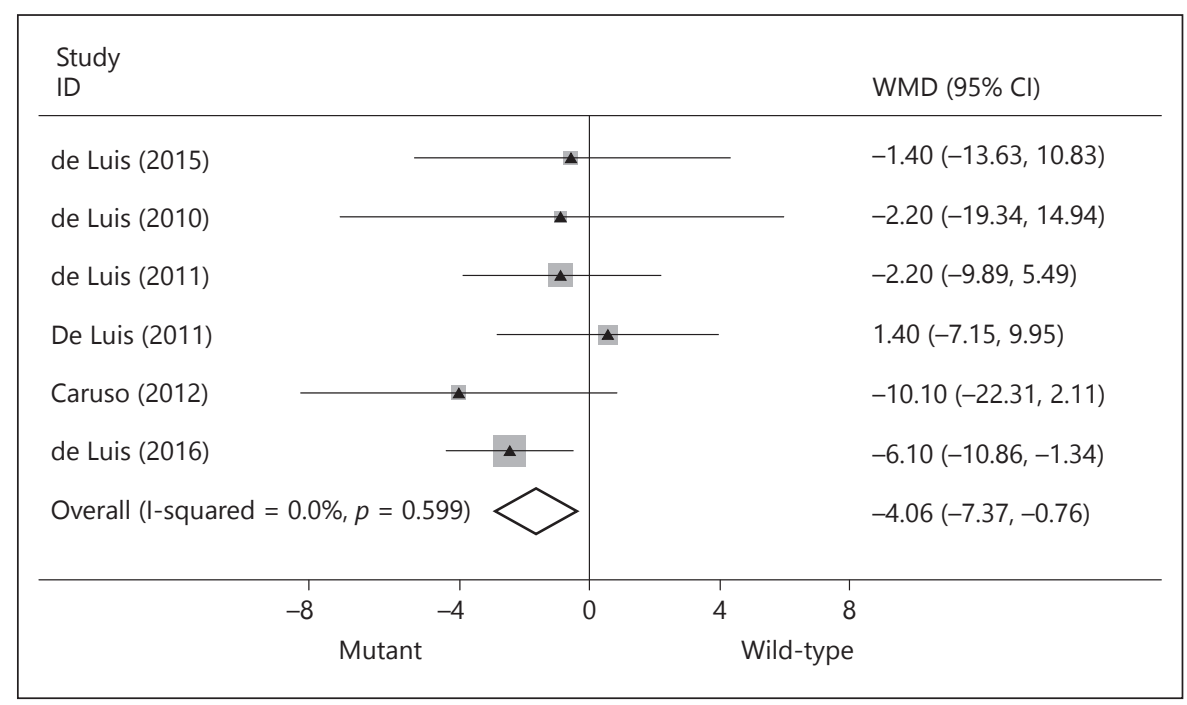

pared to the mutant-type group, subjects with wild genotype consumed $4.6 \mathrm{~g} /$ day more dietary fat; however, this difference was not statistically significant.

When we pooled 5 studies for a meta-analysis of dietary SFA, no significant difference was observed among GA/AA genotypes compared to the GG genotype $(\mathrm{WMD}=-2.42$; $95 \% \mathrm{CI}-6.70$ to $1.86 ; p=0.27)$, with a moderate heteroge- neity between studies $\left(I^{2}=45.97 \%, p<0.001\right)$. A series of sensitivity analyses did not change these results (Fig. 5).

Data from 5 publications were included in the metaanalysis for mean differences of PUFA intake. There was no significant difference between GA/AA genotypes compared to the GG genotype (WMD $=-0.44 ; 95 \% \mathrm{CI}-0.87$ to $-0.001 ; p=0.05)$. 
Fig. 5. Sensitivity analysis for the mean difference of SFA among patients with GA/ AA compared with those with GG genotype.

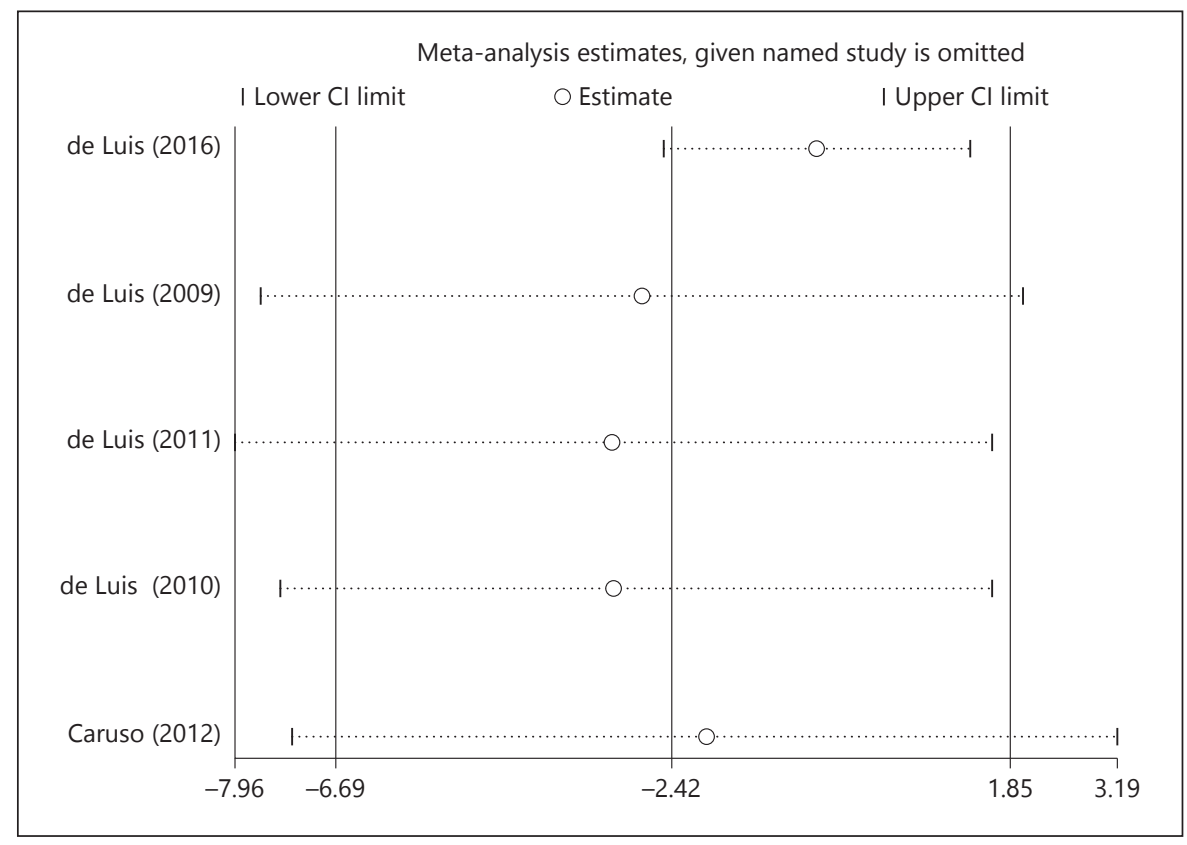

The pooled effect size for mean difference of MUFA intake estimated from 6 studies was found to be -0.96 (95\% CI -2.38 to $0.47 ; p=0.19$ ).

The pooled analysis of studies reporting data on the comparison of mean dietary carbohydrate (WMD = $-2.45 ; 95 \% \mathrm{CI}-9.31$ to $4.41 ; p=0.49)$, protein $(\mathrm{WMD}=$ $-0.60 ; 95 \% \mathrm{CI}-2.94$ to $1.75 ; p=0.62)$, and fiber (WMD = -0.26 ; $95 \%$ CI -0.81 to $0.30 ; p=0.37$ ) showed no significant difference among the mutant genotype compared to the wild genotype group.

\section{Serum Levels of Leptin}

Findings from meta-analysis on point estimates of serum concentrations of leptin also showed no significant difference among participants with GA/AA and GG genotypes $(\mathrm{WMD}=2.65 ; 95 \% \mathrm{CI}-2.05$ to $7.35 ; p=0.27$ ).

\section{Subgroup Analysis}

The subgroup analysis was done based on the quality score (measured by the Newcastle-Ottawa score) and BMI category ( $\mathrm{BMI}<30, \mathrm{BMI} \geq 30$ ) when heterogeneity was significant. There were no significant results in the subgroup analysis.

\section{Publication Bias}

No significant publication biases were observed through funnel plots and Begg's test; BMI $(p=0.82$; Fig. 6$), \mathrm{FM}(p=0.53), \operatorname{FFM}(p=0.18)$, WC $(p=0.97)$, dietary energy $(p=1.0)$, carbohydrate $(p=0.13)$, protein $(p=0.71)$, fat $(p=0.81)$, SFA $(p=0.81), \operatorname{MUFA}(p=0.81)$, PUFA $(p=0.46)$, fiber $(0.46)$, and serum levels of leptin $(p=0.54)$.

\section{Discussion}

It was found that subjects with GA/AA genotype had lower BMI compared to the GG genotype group, but no significant difference was observed for FFM, FM, and WC. There were also no significant differences for consumption of total energy, fat, protein, and carbohydrate as well as dietary fiber, SFA, and PUFA. Besides, serum concentrations of leptin were not significantly different among wild and mutant genotypes.

Our findings showed that people with GA/AA genotype had lower BMI than those of the GG genotype group. Compared to lean controls, the expression of cannabinoid 1 receptors has been suggested to be higher in adipocytes of obese animals [32]. Moreover, there is a body of evidence suggesting that the mesolimbic dopaminergic system is modulated by the endocannabinoid system [33], and BMI is increased as a result of treatment with dopamine receptor agonists [34]. In addition, an increased desire to eat was attributed to cannabinoids as their contribution to enhanced reward or hedonic properties of food [35]. However, it is not clear how the G1359A polymorphic variant affects BMI, and no evidence of amino acid substitution or levels of protein ex- 


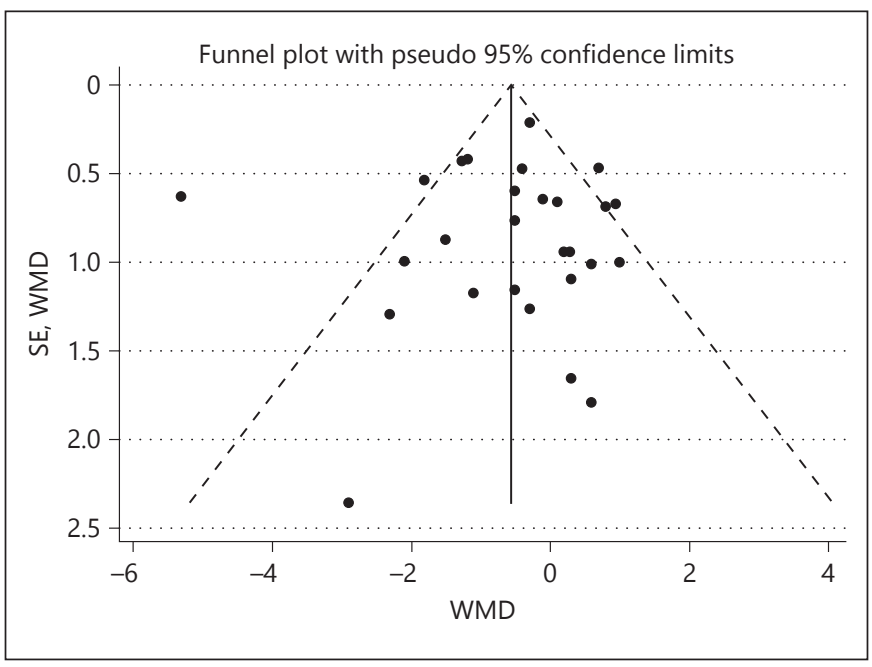

Fig. 6. Funnel plot for the mean difference of BMI among patients with GA/AA compared with those with GG genotype. WMD, weighted mean difference.

pression in mutant subjects was found to contribute to these mechanisms.

Unlike BMI, no significant difference was found for important body composition indicators. One possibility to declare this inconsistency is the presence of other polymorphism in the CNR1 gene. Total body fat and abdominal obesity were observed to be much more in patients with 3813G (rs12720071) polymorphism [36]. Researchers attempted to identify factors influencing body composition including gender. Several data detected higher levels of FM among women and larger WC among men [37], and the visceral FM was reported to increase by age in both genders [38]. Since the data could not be stratified by gender and age, it is possible that the difference in the observed BMI is partially related to age and gender differences between the groups. This might also help to explain why no differences were observed in any other parameters related to body weight or composition.

Obesity is accompanied by the loss of leptin's ability to reduce appetite and increase energy expenditure [39]. Selective CB1-receptor blockade with Rimonabant attenuates hyperleptinemia in obese subjects [40]. Since hyperleptinemia is required for the development of leptin resistance [41], a decrease in the leptin resistance contributes to the antiobesity effect of CB1 blockade. We could not find any significant difference in the serum levels of leptin among different genotypes of G1359A polymorphism. A theoretical explanation may be the fact that the participants of most studies had a mean BMI of more than 35 and, as we know, circulating concentrations of leptin are closely related to FM and BMI [42].

We included all available data on the comparison of obesity-related traits, food-related traits, and serum concentrations of leptin between G1359A variants for both healthy and non-healthy adults. Particular strengths of our study are the explanatory approach and the absence of publication bias. However, some limitations should be acknowledged for the present meta-analysis. The diversity of studies did not facilitate the performance of subgroup analysis by the participants' health condition and ethnicity. The observational approach of the meta-analysis also makes it difficult to decide about the causality. OR values were not reported in almost any of the studies to analyze the association of the G1359A polymorphism of CNR1 with health conditions including type 2 diabetes mellitus and coronary heart diseases.

Since dietary recommendations based on whole foods are growing, future studies may focus on the geneticbased dietary advice with emphasis on dietary patterns. It is recommended that studies targeting obesity provide data for G1359A polymorphism of CNR1. This information would help to provide insights into which aspect(s) of obesity is influenced by the genetic variant. Future interventions and mechanistic studies in humans are required to better understand the putative relationship between G1359A and macronutrient intake.

In conclusion, the results of the present meta-analysis study showed that compared to the wild genotype group, subjects with mutant polymorphism had lower BMI.

\section{Disclosure Statement}

None of the authors had any personal or financial conflicts of interest to disclose.

\section{References}

1 Viveros MP, de Fonseca FR, Bermudez-Silva FJ, McPartland JM: Critical role of the endocannabinoid system in the regulation of food intake and energy metabolism, with phylogenetic, developmental, and pathophysiological implications. Endocr Metab Immune Disord Drug Targets 2008;8:220-230.

2 Miller LK, Devi LA: The highs and lows of cannabinoid receptor expression in disease: mechanisms and their therapeutic implications. Pharmacol Rev 2011;63:461-470.

3 Gazzerro P, Caruso MG, Notarnicola M, Misciagna G, Guerra V, Laezza C, Bifulco M: Association between cannabinoid type-1 receptor polymorphism and body mass index in a southern Italian population. Int J Obes (Lond) 2007;31:908-912. 
4 Buraczynska M, Wacinski P, Zukowski P, Dragan M, Ksiazek A: Common polymorphism in the cannabinoid type 1 receptor gene (CNR1) is associated with microvascular complications in type 2 diabetes. J Diabetes Complications 2014;28:35-39.

$5 \mathrm{Hu}$ WC, Feng P: G1359A polymorphism in the cannabinoid receptor-1 gene is associated with metabolic syndrome in the Chinese Han population. Arch Med Res 2010; 41:378-382.

6 Gadzicki D, Muller-Vahl K, Stuhrmann M: A frequent polymorphism in the coding exon of the human cannabinoid receptor (CNR1) gene. Mol Cell Probes 1999;13:321323.

7 de Luis DA, Ballesteros M, Lopez Guzman A, Ruiz E, Munoz C, Penacho MA, Iglesias P, Maldonado A, San Martin L, Izaola O, Delgado M: Polymorphism G1359A of the cannabinoid receptor gene (CNR1): allelic frequencies and influence on cardiovascular risk factors in a multicentre study of Castilla-Leon. J Hum Nutr Diet 2016;29:112117.

8 Frost M, Nielsen TL, Wraae K, Hagen C, Piters E, Beckers S, De Freitas F, Brixen K, Van Hul W, Andersen M: Polymorphisms in the endocannabinoid receptor 1 in relation to fat mass distribution. Eur J Endocrinol 2010; 163:407-412.

9 de Luis DA, Gonzalez Sagrado M, Aller R, Izaola O, Conde R: Relation of G1359A polymorphism of the cannabinoid receptor (CB1) gene with metabolic syndrome by ATP III classification. Diabetes Metab Res Rev 2011; 27:506-511.

10 de Luis DA, Sagrado MG, Aller R, Izaola O, Conde R: Influence of G1359A polymorphism of the cannabinoid receptor gene on anthropometric parameters and insulin resistance in women with obesity. Metabolism 2011;60:272-276.

11 Lenarcik-Kabza A, Laczmanski L, Milewicz A, Bidzinska-Speichert B, Pawlak M, Kolackov K, Kuliczkowska-Plaksej J, TrzmielBira A, Brona A: The influence of endocannabinoid receptor 1 gene variations on anthropometric and metabolic parameters of women with polycystic ovary syndrome. Endokrynol Pol 2014;65:181-188.

12 de Luis DA, González Sagrado M, Aller R, Izaola O, Conde R, Romero E: G1359A polymorphism of the cannabinoid receptor gene (CNR1) and insulin resistance in patients with diabetes mellitus type 2. Nutr Hosp 2010; 25:34-38.

13 Caruso MG, Gazzerro P, Notarnicola M, Cisternino AM, Guerra V, Misciagna G, Laezza C, Bifulco M: Cannabinoid type 1 receptor gene polymorphism and macronutrient intake. J Nutrigenet Nutrigenomics 2012;5:305313.

14 de Luis DA, González Sagrado M, Aller $\mathrm{R}$, Conde R, Izaola O, de la Fuente B, Primo D: Role of G1359A polymorphism of the cannabinoid receptor gene on weight loss and adipocytokines levels after two different hypocaloric diets. J Nutr Biochem 2012; 23:287-291.

15 De Luis DA, González Sagrado M, Aller R, Conde R, Izaola O, de la Fuente B, Primo D: Roles of G1359A polymorphism of the cannabinoid receptor gene (CNR1) on weight loss and adipocytokines after a hypocaloric diet. Nutr Hosp 2011;26:317-322.

16 Moher D, Liberati A, Tetzlaff J, Altman DG: Preferred reporting items for systematic reviews and meta-analyses: the PRISMA statement. PLoS Med 2009;6:e1000097.

17 Wells G, Shea B, O'Connell D, et al: The Newcastle-Ottawa Scale (NOS) for assessing the quality of nonrandomised studies in metaanalyses. Ottawa Health Research Institute 2012 (accessed April 10, 2017).

18 Lau J, Ioannidis JP, Schmid CH: Quantitative synthesis in systematic reviews. Ann Intern Med 1997;127:820-826.

19 Luis DA, González Sagrado M, Aller R, Izaola $\mathrm{O}$, Conde R, Pérez Castrillón JL, Romero E: G1359A polymorphism of the cannabinoid receptor gene (CNR1) on anthropometric parameters and cardiovascular risk factors in patients with morbid obesity. Nutr Hosp 2009;24:688-692.

20 de Luis DA, Izaola O, Aller R, Lopez JJ, Torres B, Diaz G, Gomez E, Romero E: Association of G1359A polymorphism of the cannabinoid receptor gene (CNR1) with macronutrient intakes in obese females. J Hum Nutr Diet 2016; 29:118-123.

21 Aller R, de Luis DA, Pacheco D, Velasco MC, Conde R, Izaola O, Gonzalez Sagrado M: Influence of G1359A polimorphysm of the cannabinoid receptor gene (CNR1) on insulin resistance and adipokines in patients with non alcoholic fatty liver disease. Nutr Hosp 2012; 27:1637-1642.

22 Storr M, Emmerdinger D, Diegelmann J, Pfennig S, Ochsenkuhn T, Goke B, Lohse P, Brand S: The cannabinoid 1 receptor (CNR1) 1359 G/A polymorphism modulates susceptibility to ulcerative colitis and the phenotype in Crohn's disease. PLoS One 2010;5:e9453.

23 Wang R, Hu WC, Qiang L: G1359A polymorphism in the cannabinoid receptor-1 gene is associated with the presence of coronary artery disease in patients with type 2 diabetes. J Invest Med 2012;60:44-48.

24 Suarez-Pinilla P, Roiz-Santianez R, OrtizGarcía de la Foz V, Guest PC, Ayesa-Arriola $\mathrm{R}$, Cordova-Palomera A, Tordesillas-Gutierrez D, Crespo-Facorro B: Brain structural and clinical changes after first episode psychosis: focus on cannabinoid receptor 1 polymorphisms. Psychiatry Res 2015;233:112-119.

25 Aberle J, Flitsch J, Beck NA, Mann O, Busch P, Peitsmeier P, Beil FU: Genetic variation may influence obesity only under conditions of diet: analysis of three candidate genes. Mol Genet Metab 2008;95:188-191.

26 de Luis DA, Pacheco D, Aller R, Gonzalez Sagrado $\mathrm{M}$, Conde $\mathrm{R}$, Izaola $\mathrm{O}$, Cuellar L, Terroba MC, Martin T, Ventosa M: G1359A polymorphism of the cannabinoid receptor gene (CNR1) and clinical results of biliopancreatic diversion. Eur Rev Med Pharmacol Sci 2010;14:197-201.

27 de Luis DA, Aller R, Gonzalez Sagrado M, Conde R, Izaola O, de la Fuente B: Genetic variation in the cannabinoid receptor gene (CNR1) (G1359A polymorphism) and their influence on anthropometric parameters and metabolic parameters under a high monounsaturated vs. high polyunsaturated fat hypocaloric diets. J Nutr Biochem 2013;24:1431-1435.

28 de Luis DA, Ovalle HF, Soto GD, Izaola O, de la Fuente B, Romero E: Role of genetic variation in the cannabinoid receptor gene (CNR1) (G1359A polymorphism) on weight loss and cardiovascular risk factors after liraglutide treatment in obese patients with diabetes mellitus type 2. J Investig Med 2014;62:324-327.

29 de Luis DA, Aller R, Izaola O, Díaz Soto G, López Gómez JJ, Gómez Hoyos E, Torres B, Villar A, Romero E: Effects of a high-protein/ low-carbohydrate versus a standard hypocaloric diet on weight and cardiovascular risk factors during 9 months: role of a genetic variation in the cannabinoid receptor gene (CNR1) (G1359A polymorphism). Ann Nutr Metab 2015;66:125-131.

30 Aberle J, Fedderwitz I, Klages N, George E, Beil FU: Genetic variation in two proteins of the endocannabinoid system and their influence on body mass index and metabolism under low fat diet. Horm Metab Res 2007;39:395-397.

31 Peeters A, Beckers S, Mertens I, Van Hul W, Van Gaal L: The G1422A variant of the cannabinoid receptor gene (CNR1) is associated with abdominal adiposity in obese men. Endocrine 2007;31:138-141.

32 Bensaid M, Gary-Bobo M, Esclangon A, Maffrand JP, Le Fur G, Oury-Donat F, Soubrie P: The cannabinoid $\mathrm{CB} 1$ receptor antagonist SR141716 increases Acrp30 mRNA expression in adipose tissue of obese fa/fa rats and in cultured adipocyte cells. Mol Pharmacol 2003;63:908-914.

33 Garcia C, Palomo-Garo C, Gomez-Galvez Y, Fernandez-Ruiz J: Cannabinoid-dopamine interactions in the physiology and physiopathology of the basal ganglia. Br J Pharmacol 2016;173:2069-2079.

34 Frank GK, Shott ME, Hagman JO, Schiel MA, DeGuzman MC, Rossi B: The partial dopamine D2 receptor agonist aripiprazole is associated with weight gain in adolescent anorexia nervosa. Int J Eat Disord 2017;50:447450.

35 Pecina S, Berridge KC: Opioid site in nucleus accumbens shell mediates eating and hedonic 'liking' for food: map based on microinjection Fos plumes. Brain Res 2000;863:71-86.

36 Russo P, Strazzullo P, Cappuccio FP, Tregouet DA, Lauria F, Loguercio M, Barba G, Versiero $\mathrm{M}$, Siani A: Genetic variations at the endocannabinoid type 1 receptor gene (CNR1) are associated with obesity phenotypes in men. J Clin Endocrinol Metab 2007;92:2382-2386. 
37 Benzinou M, Chevre JC, Ward KJ, Lecoeur C, Dina C, Lobbens S, Durand E, Delplanque J, Horber FF, Heude B, Balkau B, Borch-Johnsen K, Jorgensen T, Hansen T, Pedersen O, Meyre D, Froguel P: Endocannabinoid receptor 1 gene variations increase risk for obesity and modulate body mass index in European populations. Hum Mol Genet 2008;17:1916-1921.

38 Wajchenberg BL: Subcutaneous and visceral adipose tissue: their relation to the meta- bolic syndrome. Endocr Rev 2000;21:697738.

39 Matias I, Carta G, Murru E, Petrosino S, Banni S, Di Marzo V: Effect of polyunsaturated fatty acids on endocannabinoid and $\mathrm{N}$ acyl-ethanolamine levels in mouse adipocytes. Biochim Biophys Acta 2008;1781:5260.

40 Dardeno TA, Chou SH, Moon HS, Chamberland JP, Fiorenza CG, Mantzoros CS: Leptin in human physiology and therapeutics. Front Neuroendocrinol 2010;31:377-393.

41 Despres JP, Golay A, Sjostrom L: Effects of rimonabant on metabolic risk factors in overweight patients with dyslipidemia. N Engl J Med 2005;353:2121-2134.

42 Knight ZA, Hannan KS, Greenberg ML, Friedman JM: Hyperleptinemia is required for the development of leptin resistance. PLoS One 2010;5:e11376. 